\title{
Enhancement of OVA-induced murine lung eosinophilia by co-exposure to contamination levels of LPS in Asian sand dust and heated dust
}

Yahao Ren ${ }^{1}$, Takamichi Ichinose ${ }^{2 *}$, Miao He ${ }^{3}$, Yuan Song ${ }^{4}$, Yasuhiro Yoshida ${ }^{4}$, Seiichi Yoshida ${ }^{2}$, Masataka Nishikawa ${ }^{5}$, Hirohisa Takano ${ }^{6}$, Guifan Sun ${ }^{3^{*}}$ and Takayuki Shibamoto ${ }^{7}$

\begin{abstract}
Background: A previous study has shown that the aggravation of Asian sand dust (ASD) on ovalbumin (OVA)-induced lung eosinphilia was more severe in lipopolysaccharide (LPS)-rich ASD than in $\mathrm{SiO}_{2}$-rich ASD. Therefore, the effects of different LPS contamination levels in ASD on the aggravation of OVA-induced lung eosinophilia were investigated in the present study.
\end{abstract}

Methods: Before beginning the in vivo experiment, we investigated whether the ultra-pure LPS would act only on TLR4 or not using bone marrow-derived macrophages (BMDMs) of wild-type, TLR2-/-, TLR4-/- and MyD88-/BALB/c mice. ASD collected from the desert was heated to remove toxic organic substances (H-ASD). BALB/c mice were instilled intratracheally with 12 different testing samples prepared with LPS (1 ng and $10 \mathrm{ng}$ ), H-ASD, and OVA in a normal saline solution. The lung pathology, cytological profiles in the bronchoalveolar lavage fluid (BALF), the levels of inflammatory cytokines/chemokines in BALF and OVA-specific immunoglobulin in serum were investigated.

Results: The LPS exhibited no response to the production of TNF- $a$ and IL-6 in BMDMs from TLR4-/-, but did from TLR2-/-. H-ASD aggravated the LPS-induced neutrophilic lung inflammation. In the presence of OVA, LPS increased the level of eosinophils slightly and induced trace levels of Th2 cytokines IL-5 and IL-13 at the levels of $1 \mathrm{ng}$ and $10 \mathrm{ng}$. In the presence of OVA and H-ASD, LPS induced severe eosinophil infiltration and proliferation of goblet cells in the airways as well as remarkable increases in Th2 cytokines IL-5 and IL-13 in BALF. The mixture containing LPS (1 ng) showed adjuvant activity on OVA-specific lgE and lgG1 production.

Conclusions: The results suggest that H-ASD with naturally-occurring levels of LPS enhances OVA-induced lung eosinophilia via increases in Th2-mediated cytokines and antigen-specific immunoglobulin. These results indicate that LPS is a strong candidate for being a major aggravating substance in ASD.

Keywords: Lipopolysaccharide, Asian sand dust, Ovalbumin, Lung eosinophilia, Cytokine and chemokine, Asthma

\section{Background}

Asian sand dust (ASD) is observed most frequently in the spring. When a large scale sandstorm occurs in Northern China and Mongolia, ASD aerosol spreads over large areas, including East China, the Korean Peninsula and Japan as well as crossing the North Pacific to the United

\footnotetext{
* Correspondence: ichinose@oita-nhs.ac.jp; sungf@mail.cmu.edu.cn

${ }^{2}$ Department of Health Sciences, Oita University of Nursing and Health

Sciences, Oita 870-1201, Japan

${ }^{3}$ Department of Environmental and Occupational Health, College of Public

Health, China Medical University, Shenyang, China

Full list of author information is available at the end of the article
}

States [1-3]. In recent years, ASD has received more and more attention as the adverse effects on human health become known. Epidemiological studies suggested that ASD events may be associated with increased death rates due to respiratory and circulatory diseases $[4,5]$. Some reports also suggest that ASD events are associated with increased respiratory symptoms in both adults and children with asthma [6,7].

Our previous studies have shown that ASD had aggravating effects on ovalbumin (OVA) - induced lung eosinophilia, whereas ASD heated at $360^{\circ} \mathrm{C}$ to exclude organic 
substances and chemicals (H-ASD) caused fewer effects $[8,9]$. On the basis of these results, we speculate that the organic substances and chemicals adhering to ASD may contribute to the aggravation of lung eosinophila. Microbial and by-product materials derived from air-pollutants, including polycyclic aromatic hydrocarbons (PAHs), sulfates $\left(\mathrm{SO}_{4}^{2-}\right)$ and nitrates $\left(\mathrm{NO}_{3}^{-}\right)$, adhere onto ASD during long-range transportation of the dust [10-12]. ASD was contaminated with trace levels of LPS, which is a cell wall component of gram-negative bacteria. Epidemiological studies suggest that endotoxin levels in samples from children's mattress were inversely related to the occurrence of atopic asthma [13]. On the other hand, some other studies have shown that endotoxin exposure is positively associated with an increased risk of asthma and asthma severity in both adults and children [14,15]. The results of animal studies are also somewhat contradictory. Interestingly, some studies suggest that LPS at a low dose facilitates a Th2 response to allergens, while LPS at a high dose favors Th1 inflammation [16,17]. Our recent study has shown that the aggravation of murine lung eosinophilia was more severe in LPS-rich ASD than in $\mathrm{SiO}_{2}$-rich ASD [18]. Therefore, experimental study as to whether the levels of LPS contamination in ASD are significantly related to the degree of aggravation of the lung eosinophilia is in order.

In the present study, the exacerbating effects of low levels of LPS and/or H-ASD on OVA-induced lung eosinophilia were investigated using $\mathrm{BALB} / \mathrm{c}$ mice.

\section{Materials and methods \\ Animals}

Specific pathogen-free male BALB/c mice (6 weeks of age) were obtained from Charles River Japan, Inc. (Kanagawa, Japan). The body weight of the mice and the presence of infection were checked for 1 week. The mice used were 7 weeks of age. CE-2 commercial diet (CLEA Japan, Tokyo, Japan) and water were given ad libitum. The mice were housed in plastic cages lined with soft wood chips. The cages were placed in a conventional room, which was air conditioned at $23^{\circ} \mathrm{C}$ with a light/dark $(12 \mathrm{~h} / 12 \mathrm{~h})$ cycle, and humidity ranging from 55 to $70 \%$. The study adhered to the US National Institutes of Health guidelines for the use of experimental animals. The animal care method was also approved by the animal care and use committee at Oita University of Nursing and Health Sciences in Oita, Japan.

\section{Preparation of particles and LPS}

The Asian dust used as the standard base for the samples in this study was collected from surface soils in the Gobi desert and purified for use in the present study. The size distribution peak was observed at $3.9 \mu \mathrm{m}$. The chemical elements in ASD were as reported previously: $51.6 \% \mathrm{SiO}_{2}$, 14.3\% $\mathrm{Al}_{2} \mathrm{O}_{3}, 5.5 \% \mathrm{Fe}_{2} \mathrm{O}_{3}, 1.3 \% \mathrm{Na}_{2} \mathrm{O}, 9.6 \% \mathrm{CaCO}_{3}, 0.6 \%$
$\mathrm{CaO}, 2.5 \% \mathrm{MgO}, 0.7 \% \mathrm{TiO}_{2}$ and $2.6 \% \mathrm{~K}_{2} \mathrm{O}$. And, as in the previous study, $11.3 \%$ of total oxides were lost at ig [19]. A portion of the standard ASD was heated at $360^{\circ} \mathrm{C}$ for $30 \mathrm{~min}$ in an electric heater to exclude toxic materials (sulfate, nitrate, microorganism, etc.). These samples are termed H-ASD in the present study. Ultra pure LPS was purchased from InvivoGen (San Diego, CA, USA).

\section{Study protocol}

One hundred and sixty eight BALB/c mice were divided into twelve groups $(\mathrm{n}=14$ per group) and each group was treated with a specific testing sample. The 12 testing samples $(0.1 \mathrm{~mL}$ each of $0.9 \% \mathrm{NaCl}$ normal saline solution) prepared for the present study were control (containing normal saline alone); H-ASD (0.1 mg H-ASD alone); LPS 1 (1 ng LPS alone); LPS 10 (10 ng LPS alone); H-ASD + LPS 1 (0.1 mg H-ASD and $1 \mathrm{ng}$ LPS); H-ASD + LPS 10 (0.1 mg H-ASD and $10 \mathrm{ng}$ LPS); OVA (2 $\mu \mathrm{g}$ OVA alone); OVA + H-ASD $(2 \mu \mathrm{g}$ OVA and $0.1 \mathrm{mg}$ H-ASD); OVA + LPS 1 ( $2 \mu \mathrm{g}$ OVA and $1 \mathrm{ng}$ LPS); OVA + LPS 10 (2 $\mu \mathrm{g}$ OVA and 10 ng LPS); OVA + $\mathrm{H}$-ASD + LPS $1(2 \mu \mathrm{g}$ OVA, $0.1 \mathrm{mg} \mathrm{H}-\mathrm{ASD}$, and $1 \mathrm{ng}$ LPS); and OVA + H-ASD + LPS 10 (2 $\mu \mathrm{g}$ OVA, $0.1 \mathrm{mg}$ $\mathrm{H}$-ASD, and $10 \mathrm{ng}$ LPS). The mice were intratracheally challenged with a mixed or individual solution of OVA, H-ASD and LPS 4 times at 2-week intervals. The control group was instilled intratracheally with $0.1 \mathrm{ml}$ normal saline.

\section{Bronchoalveolar lavage fluid (BALF)}

Eight out of 14 mice were used for an examination of the free cell contents in BALF. BALF and cell counts were conducted using a previously reported method $[18,20]$. Briefly, the lungs were lavaged with two injections of $0.8 \mathrm{ml}$ of sterile saline at $37^{\circ} \mathrm{C}$. After the fluids from the two lavages were combined and cooled to $4^{\circ} \mathrm{C}$, the resultant solution was centrifuged at $1500 \mathrm{rpm}$ for $10 \mathrm{~min}$. The protein levels of cytokines and chemokines in the BALF were measured. The total cell count of the fresh fluid specimen was determined by a hemocytometer. Differential cell counts were assessed on cytological preparations. Slides were prepared using a Cytospin (Sakura Co., Ltd, Tokyo, Japan) and stained with Diff-Quik (International Reagents Co., Kobe, Japan) to identify the eosinophils with red granules. A total of 300 cells were counted under a microscope. The BALF supernatants were stored at $-80^{\circ} \mathrm{C}$ to await analysis for cytokines and chemokines.

\section{Pathological evaluation}

The remaining 6 mice in each group were used for pathological examination. The lungs were fixed by $10 \%$ neutral phosphate-buffered formalin. After separation of the lobes, 2-mm-thick blocks were taken for paraffin embedding. Embedded blocks were sectioned at a thickness of $3 \mu \mathrm{m}$, 
and then stained with hematoxylin and eosin ( $\mathrm{H} \& \mathrm{E})$ to evaluate the degree of infiltration of eosinophils and lymphocytes in the airway from proximal to distal. The sections were stained with periodic acid-Schiff (PAS) to evaluate the degree of proliferation of goblet cells in the bronchial epithelium. A pathological analysis of inflammatory cells and epithelial cells in the airway was performed using a Nikon ECLIPSE light microscope (Nikon Co., Tokyo, Japan). The degree of infiltration of eosinophils and lymphocytes in the airway or proliferation of goblet cells in the bronchial epithelium was graded in a blinded fashion: 0 , not present; 1 , slight; 2, mild; 3, moderate; 4, moderate to marked; 5, marked. 'Slight' was defined as less than $20 \%$ of the airway with eosinophilic inflammatory reaction or with goblet cells stained with PAS; 'mild' as 21 - 40\%; 'moderate' as 41 $60 \%$; 'moderate to marked' as 61 - $80 \%$; and marked as more than $80 \%$ of the airway $[18,20]$.

\section{Quantitation of cytokines and chemokines in BALF}

The cytokine and chemokine protein levels were determined by enzyme-linked immunosorbent assays (ELISA). IL-5 and IL-12 were measured using an ELISA kit from Endogen, Inc. (Cambridge, MA, USA). MCP-3 was measured using an ELISA kit from Bender MedSystems Inc.
(Burlingame, CA, USA). IL-1ß, IL-4, IL-6, IL-13, IL-17A, IFN- $\gamma$, KC, TNF- $\alpha$, TGF- $\beta$, Eotaxin, MCP-1, MIP- $1 \alpha$, RANTES were measured using an ELISA kit from R\&D Systems Inc. (Minneapolis, MN, USA).

\section{OVA-specific IgE and IgG1 antibodies}

OVA-specific immunoglobulin E (IgE) and IgG1 antibodies were measured using the Mouse OVA-IgE ELISA kit and Mouse OVA-IgG1 ELISA kit (Shibayagi Co., Shibukawa, Japan). According to the manufacturer's protocol, $1 \mathrm{U}$ of the anti-OVA IgE is defined as $1.3 \mathrm{ng}$ of the antibody; and $1 \mathrm{U}$ of the anti-OVA IgG1 is defined as $160 \mathrm{ng}$ of the antibody. The absorption of $450 \mathrm{~nm}$ (subwave length, $620 \mathrm{~nm}$ ) for OVA-specific IgE and IgG1 antibody was measured by a microplate reader (Spectrafluor, Tecan, Salzburg, Austria).

\section{Isolation and culture of murine bone marrow-derived macrophages (BMDMs)}

Wild-type, TLR2-/-, TLR4-/- and MyD88-/- mice (on BALB/c background) were purchased from Oriental Bioservice, Inc (Kyoto, Japan). Femurs were removed at 8 weeks of age, the soft tissue removed, and flushed with Hanks to recover the bone marrow. BMDMs were cultured on plastic dishes in RPMI (Nissui, Tokyo,

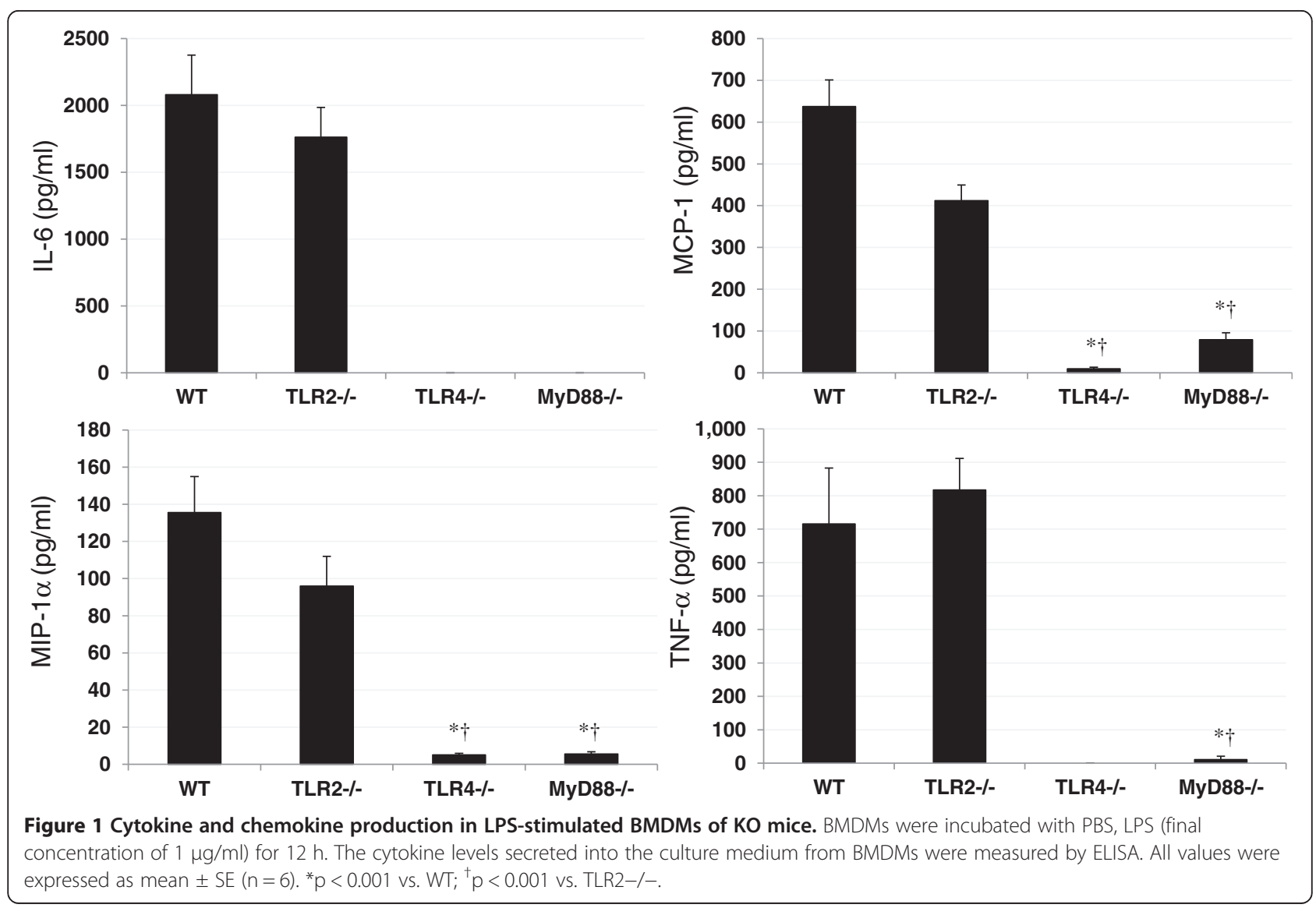


Japan) containing penicillin/streptomycin (Gibco, New York, NY) and 10\% inactivated fetal bovine serum (Thermo Scientific, South Logan, UT). $10 \mathrm{ng} / \mathrm{ml}$ of GM-CSF (PeproTech EC, London, UK) was added to the culture on days 0 and 3. After 6 days in culture, the adherent BMDMs were collected by adding 0.02\% $5 \mathrm{ml}$ EDTA and then scraping the loose cells off. Then BMDMs were re-plated at a concentration of $3 \times 10^{5}$ cells $/ \mathrm{ml}$ into 24-well plates at $1 \mathrm{ml} /$ well. BMDMs were incubated with PBS or LPS (final $1 \mu \mathrm{g} / \mathrm{ml}$ ) for $12 \mathrm{~h}$. Cytokines secreted into the culture medium by BMDMs were measured by ELISA.

\section{Assay for cytokines and chemokines in cell culture medium}

The protein levels of cytokines and chemokines in the nutrient medium were determined by ELISA. IL-6, MCP-1, MIP- $1 \alpha$, and TNF- $\alpha$ were measured using ELISA kits from $R \& D$ Systems Inc.

\section{Statistical analysis}

Statistical analysis on the pathological evaluation in the airway, cytokines, and chemokine proteins in BALF were conducted using the Tukey Test for Pairwise Comparisons
(KyPlot Ver 5.0, Kyens Lab Inc, Tokyo, Japan). Differences among groups were determined as statistically significant at a level of $\mathrm{p}<0.05$.

\section{Results}

Cytokines and chemokines in cell culture medium from mice treated by LPS

Figure 1 shows the amounts of cytokine and chemokine produced in LPS-stimulated BMDMs of KO mice. Relatively high levels of IL-6, MCP-1, MIP- $1 \alpha$ and TNF- $\alpha$ were found in WT cells, ranging from $136 \pm 19.4 \mathrm{pg} / \mathrm{ml}$ (MIP-1 $\alpha$ ) to $2,080 \pm 297 \mathrm{pg} / \mathrm{ml}$ (IL-6), and TLR2-/- cells, ranging from $96.0 \pm 16.0 \mathrm{pg} / \mathrm{ml}(\mathrm{MIP}-1 \alpha)$ to $1,763 \pm$

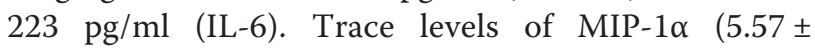
$1.20 \mathrm{pg} / \mathrm{ml})$ and TNF- $\alpha(10.4 \pm 10.4 \mathrm{pg} / \mathrm{ml})$ were observed in MyD88-/- cells, and they reduced significantly compared with WT cells. On the other hand, IL- 6 and TNF- $\alpha$ were not detected in TLR4-/- cells. IL-6 was also not detected in MyD88-/- cells.

\section{The cell numbers in BALF from mice treated by OVA,} $\mathrm{H}-\mathrm{ASD}$ and LPS

Figure 2 shows the cellular profiles in BALF. The total cell numbers ranged from $(12.8 \pm 1.92) \times 10^{4}$ (control) to

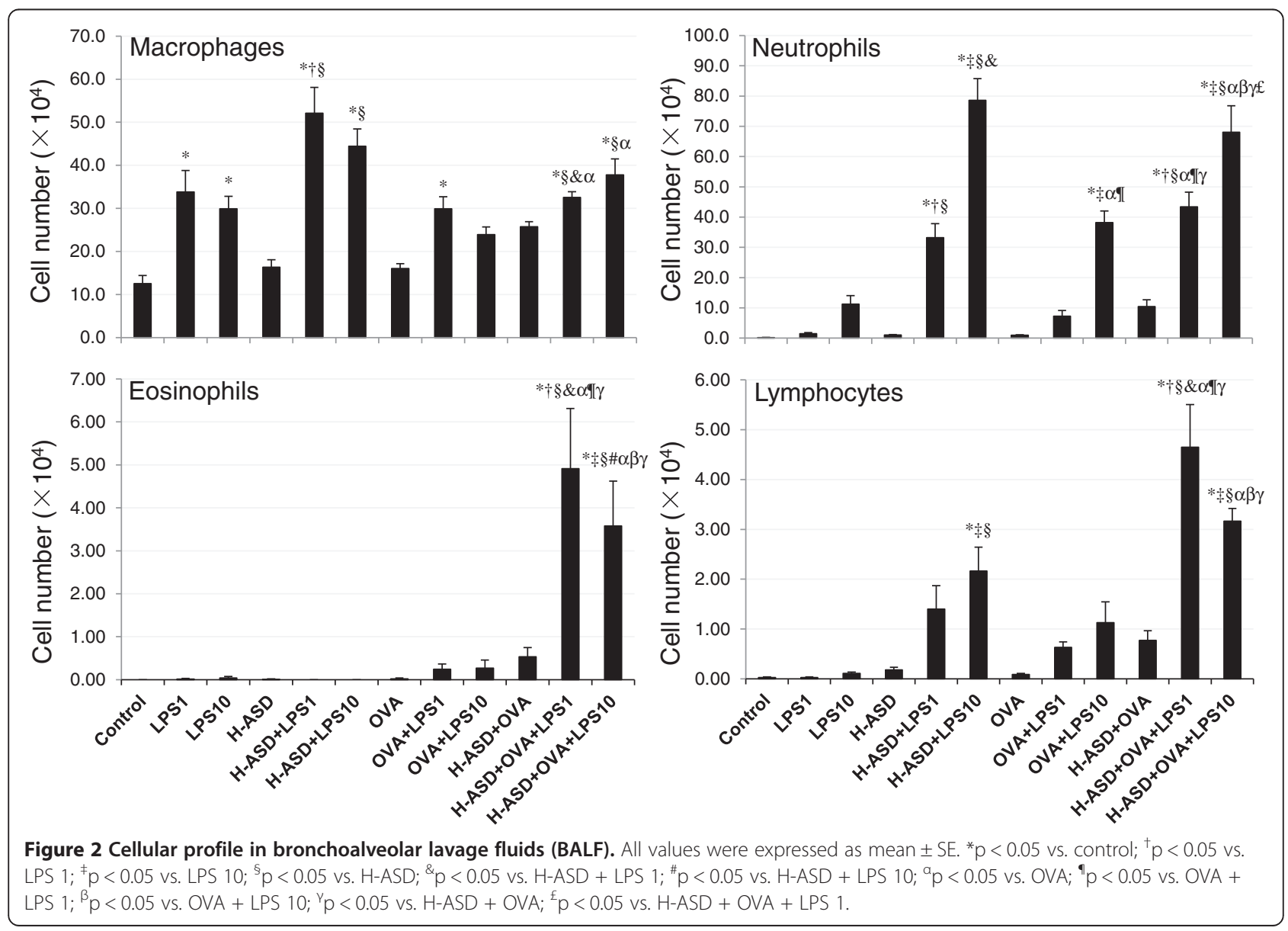


$(113 \pm 9.33) \times 10^{4}(\mathrm{H}-\mathrm{ASD}+\mathrm{OVA}+\mathrm{LPS} 10)$. The cell numbers in the control samples ranged from 0 (eosinophils) to $(12.6 \pm 1.89) \times 10^{4}$ (macrophages). LPS 1 and LPS 10 increased the number of macrophages by $168 \%$ and 137\%, respectively. The addition of H-ASD to LPS 1 and LPS 10 increased macrophages, netrophils and lymphocytes significantly, whereas no change was observed in eosinophils. OVA alone did not increase any cell numbers but the addition of LPS 1 and LPS 10 increased all cell numbers in BALF samples slightly. When LPS $1+\mathrm{H}$-ASD and LPS $10+\mathrm{H}$-ASD were added to OVA, a significant increase of numbers of all cells was observed. The increase was dose dependent in macrophages and neutrophils but not in eosinophils and lymphocytes.

\section{Cellular changes in the airways of mice treated by OVA, H-ASD and LPS}

Figure 3 shows the cellular changes caused by H-ASD and LPS in the murine airway. The pathological score ranged from 0 (eosinophils) to $3.42 \pm 0.15$ (lymphocytes). When the control, LPS 1, LPS 10, H-ASD and H-ASD + LPS 1 samples were exposed, a moderate increase in lymphocytes, ranging from $0.25 \pm 0.11$ (LPS 1) to $0.58 \pm$ 0.08 (H-ASD + LPS 1), was observed along with a slight increase of goblet cells ranging from $0.17 \pm 0.11$ (LPS 1 , LPS 10, H-ASD) to $0.25 \pm 0.11(\mathrm{H}-\mathrm{ASD}+\mathrm{LPS} 1)$. Eosinopils were not detected. When H-ASD + LPS 10, OVA, OVA + LPS 1, OVA + LPS 10 and H-ASD + OVA were exposed, moderate increases of all cells ranged from $0.25 \pm 0.11$ (eosinophils) to $1.67 \pm 0.25$ (goblet cells) occurred. The samples exposed to H-ASD + OVA + LPS 1 and H-ASD + OVA + LPS 10 showed a significant increase in goblet cells $(3.25 \pm 0.11$ and $2.75 \pm 021$, respectively) eosinophils ( $2.92 \pm 0.15$ and $2.50 \pm 0.18$, respectively) and lymphocytes ( $3.42 \pm 0.15$ and $3.08 \pm 0.20$, respectively) in the submucosa of the airway. It is interesting that the pathological change was greater with low dose $(1 \mathrm{ng})$ addition of LPS than by with $10 \mathrm{ng}$ LPS.

Figures 4 and 5 illustrate the effects of LPS on pathological changes in the lungs. No pathological alterations were found in the lungs of the control group. LPS 1 and LPS 10 caused slight infiltration of neutrophils in the submucosa of the airway, while H-ASD + LPS 1 and HASD + LPS 10 caused slight proliferation of goblet cells

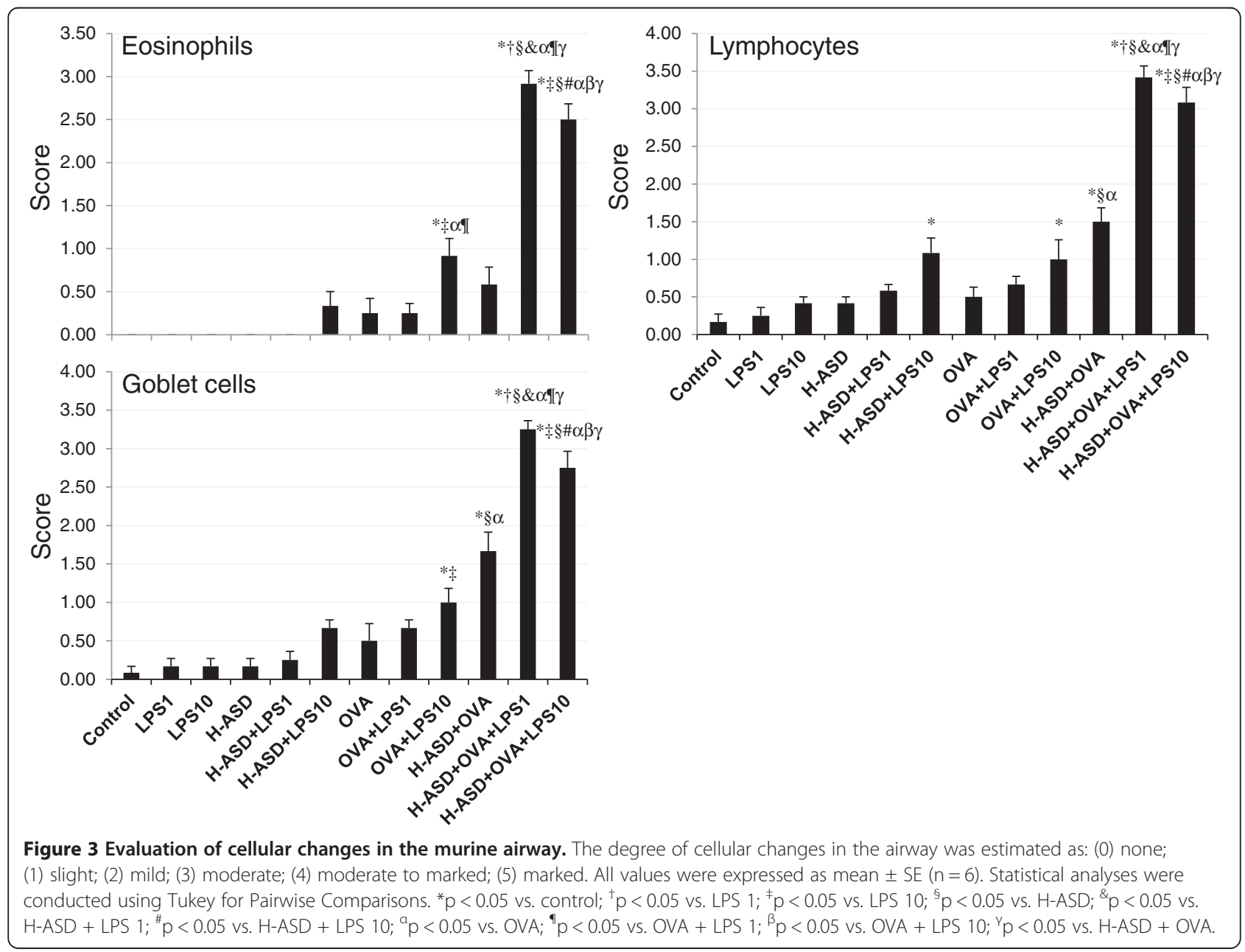




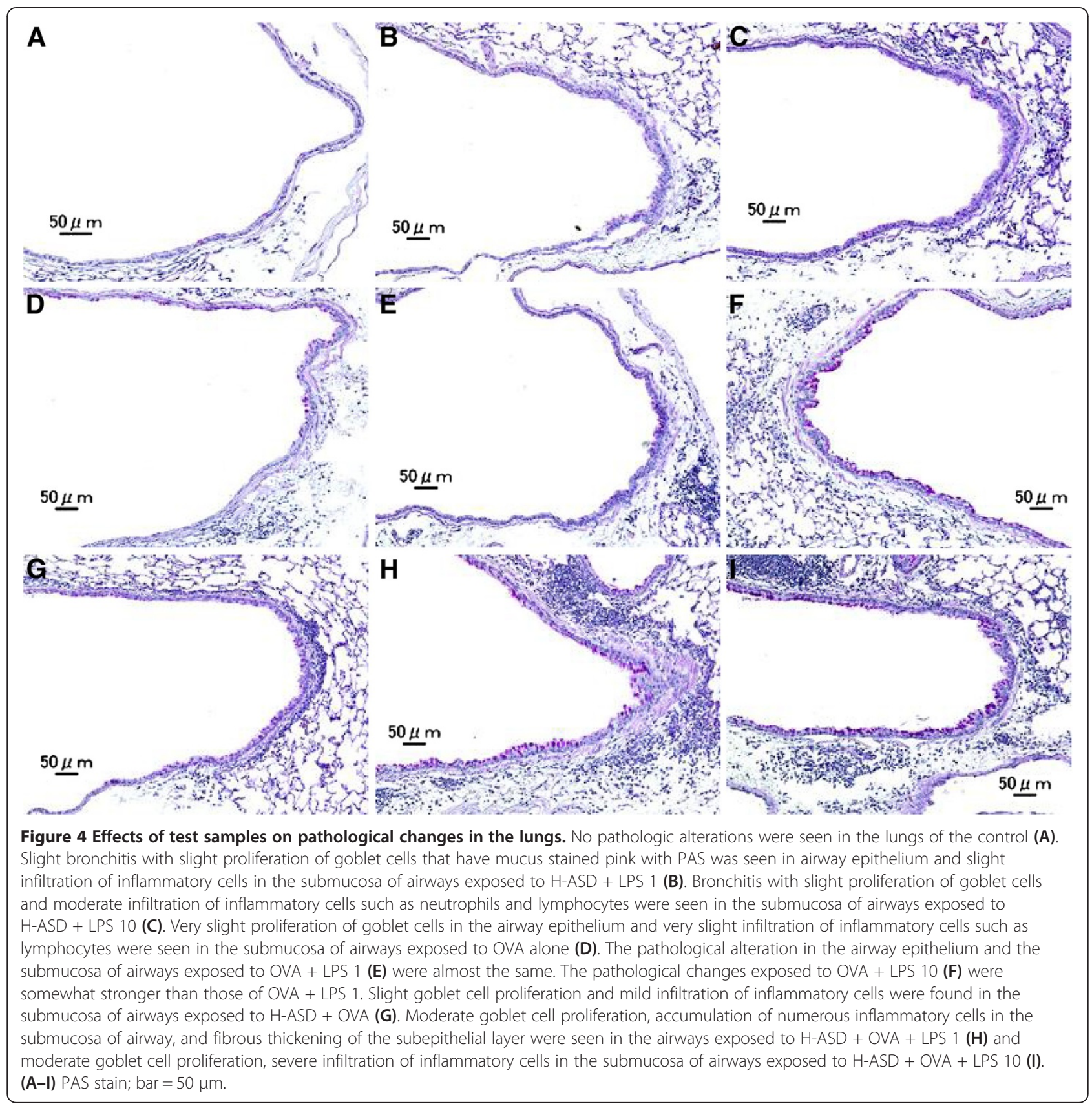

in the airway epithelium (Figure $4 \mathrm{~B}$ and $\mathrm{C}$ ) and slight to moderate infiltration of neutrophils in the airway (Figure 5B and C). OVA alone caused a slight proliferation of goblet cells in the airway epithelium (Figure 4D) as well as eosinophils, neutrophils and lymphocytes in the submucosa of airway (Figure 5D).

The pathological alteration in the airway epithelium and the submucosa of airways exposed to OVA alone and OVA + LPS 1 were almost the same (Figure 4D, F; Figure 5D, F). However, the pathological changes in samples exposed to OVA + LPS 10 were somewhat higher than those exposed to OVA + LPS 1 (Figure 4E and F). H-ASD + OVA also caused slight goblet cell proliferation and slight infiltration of eosinophils and lymphocytes in the submucosa of airway. However, H-ASD + OVA + LPS 1 and H-ASD + OVA + LPS 10 caused moderate goblet cell proliferation in the airway epithelium (Figure $4 \mathrm{H}$ and I) and moderate to marked accumulation of eosinophils, neutrophils and lymphocytes in the submucosa of airways (Figure $5 \mathrm{H}$ and I). These pathological alterations in the H-ASD + OVA + LPS 1 group were more severe than in the H-ASD + OVA + LPS 10 group. 


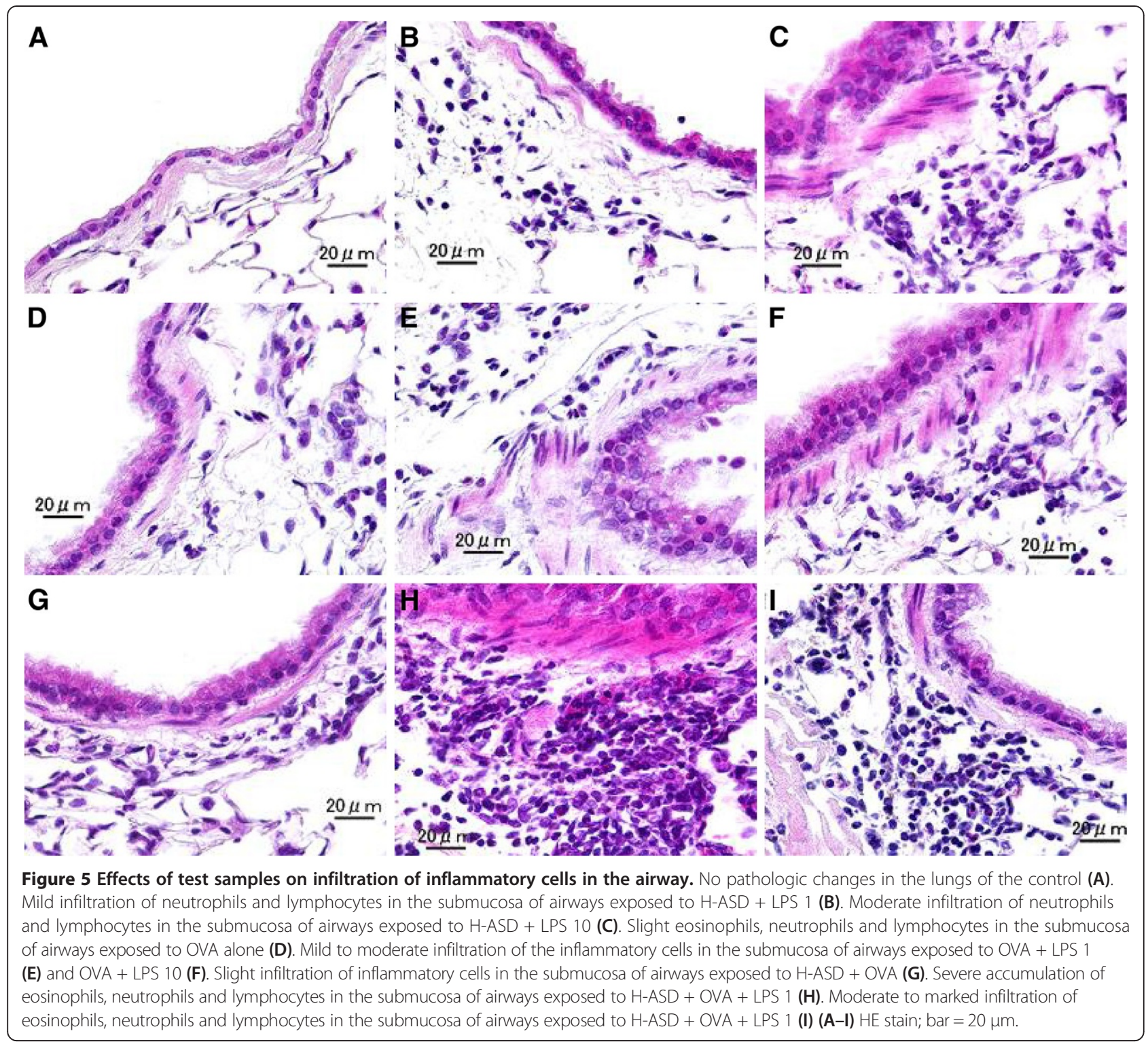

Protein levels of cytokines and chemokines in BALF from mice treated by OVA, H-ASD and LPS

Figure 6 shows the levels of IL-12, KC, MCP-1 and RANTES in BALF. The protein levels in the control ranged from not detected (IL-12) to $22.8 \pm 1.27 \mathrm{pg} / \mathrm{ml}$ (KC). LPS 1 alone did not significantly increase the proteins examined, whereas LPS 10 increased them appreciably, to levels ranging from $5.14 \pm 1.28 \mathrm{pg} / \mathrm{ml}$ (MCP-1) to $145 \pm 32.5 \mathrm{pg} / \mathrm{ml}$ (IL-12). H-ASD increased IL-12, $\mathrm{KC}$, and MCP-1. H-ASD + LPS increased all proteins. In particular, the addition of LPS 10 to H-ASD increased IL- 12 by $99 \%$ and RANTES by $1179 \%$. The amount of proteins found in the samples treated with OVA alone ranged from $1.39 \pm 0.52 \mathrm{pg} / \mathrm{ml}(\mathrm{MCP}-1)$ to $25.8 \pm 4.17(\mathrm{KC})$. The addition of LPS to OVA showed a dose-dependent increase in all proteins. When LPS was added to an OVA + H-ASD sample, all proteins also showed a dose-dependent increase.

Figure 7 shows the expression of IL- $1 \beta$, IL- 6, MIP- $1 \alpha$ and TNF- $\alpha$. The protein levels in the control samples ranged from not detected (TNF- $\alpha$ ) to $7.82 \pm 3.17 \mathrm{pg} / \mathrm{ml}$ (IL-1 $\beta)$. LPS increased all proteins dose-dependently. $\mathrm{H}$-ASD increased but OVA reduced all proteins. H-ASD alone increased IL- $1 \beta$ significantly, by $218 \%$. Addition of LPS 10 to H-ASD increased IL- 6 by $327 \%$ but LPS 1 reduced IL- 6 slightly (by $11 \%$ ). The amount of proteins found in samples treated by OVA ranged from 0 (TNF- $\alpha$ ) to $2.31 \pm 0.51 \mathrm{pg} / \mathrm{ml}$ (IL-1ß). Addition of LPS 10 to OVA increased IL- $1 \beta$ from $2.31 \pm 0.51 \mathrm{pg} / \mathrm{ml}$ to $5.92 \pm$ $0.82 \mathrm{pg} / \mathrm{ml}$, whereas addition of LPS 1 to OVA decreased it to $1.79 \pm 0.44 \mathrm{pg} / \mathrm{ml}$. Addition of LPS to H-ASD + OVA dose-dependently increased all proteins considerably. The 


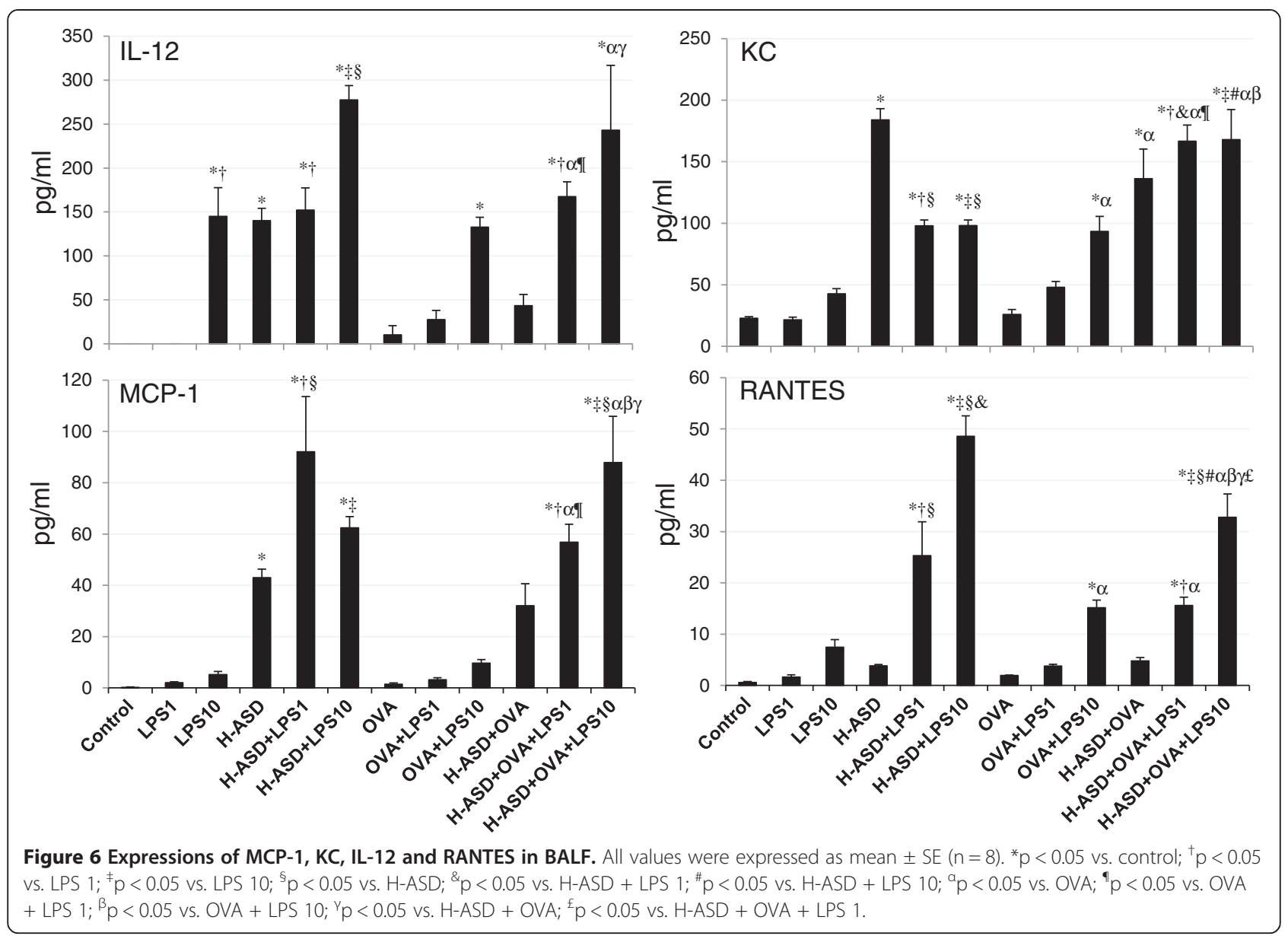

mice treated by H-ASD + OVA + LPS 10 contained the highest levels of all proteins, ranging from $12.3 \pm$ $2.3 \mathrm{pg} / \mathrm{ml}(\mathrm{TNF}-\alpha)$ to $29.2 \pm 4.31 \mathrm{pg} / \mathrm{ml}$ (MIP- $1 \alpha)$.

Figure 8 shows the expression of IL-5, IL-13, eotaxin and MCP-3 in BALF. These proteins are known as allergy associated mediators. The amount in the control group of samples ranged from not detected (IL-13) to $6.76 \pm 0.94 \mathrm{pg} / \mathrm{ml}$ (MCP-3). Among the proteins in this group, MCP-3 was detected in the highest levels in all samples from treated mice except one set of sample from $\mathrm{H}$-ASD treatment, ranging from not detected (H-ASD) to $65.3 \pm 16.3 \mathrm{pg} / \mathrm{ml}$ (H-ASD + OVA + LPS 10). When LPS was added to H-ASD, slight, dose-dependent increases of all proteins were observed.

A slight increase of all proteins was observed in the samples treated by OVA alone, ranging from $1.14 \pm$ $0.38 \mathrm{pg} / \mathrm{ml}$ (IL-13) to $10.8 \pm 0.87 \mathrm{pg} / \mathrm{ml}$ (MCP-3). Addition of LPS to OVA increased IL-5 significantly but the other samples increased only slightly. Addition of H-ASD to OVA increased IL-5 considerably from $1.68 \pm 0.51 \mathrm{pg} / \mathrm{ml}$ to $21.5 \pm 6.78 \mathrm{pg} / \mathrm{ml}$. The addition of LPS to OVA $+\mathrm{H}-$ ASD triggered a remarkable increase in all proteins. However, the increasing levels of IL-5 and IL-13 in the group treated with LPS 1 (448\% and 302\%, respectively) were higher than those of the group treated with LPS 10 ( $211 \%$ and $133 \%$, respectively).

Figure 9 shows the expression of IL-4 and IL-17A. They were not detected in the samples of the control, LPS 1, LPS 10, or H-ASD groups. The amounts of IL-4 ranged from not detected to $2.55 \pm 1.52 \mathrm{pg} / \mathrm{ml}$ (H-ASD + OVA + LPS 1) and IL-17A ranged from not detected to $14.6 \pm 5.14$ (H-ASD + OVA + LPS 10). IL-4 and IL-17A were not present in significant amounts in the samples treated with H-ASD + LPS 1, OVA, OVA + LPS 1 and $\mathrm{H}$-ASD + OVA but H-ASD and LPS obviously increased both proteins.

In the present study, TGF- $\beta$ and IFN- $\gamma$ were not detected.

\section{Enhancement of OVA-specific IgE and IgG1 by H-ASD and LPS}

Figure 10 shows the effects of testing samples on IgE and IgG1 production in serum. IgE and IgG1 were not detected in the samples of the control, LPS 1, LPS 10, H-ASD, H-ASD + LPS 1 or H-ASD + LPS 10 samples. Trace levels of IgE were observed in OVA but not IgG1. 


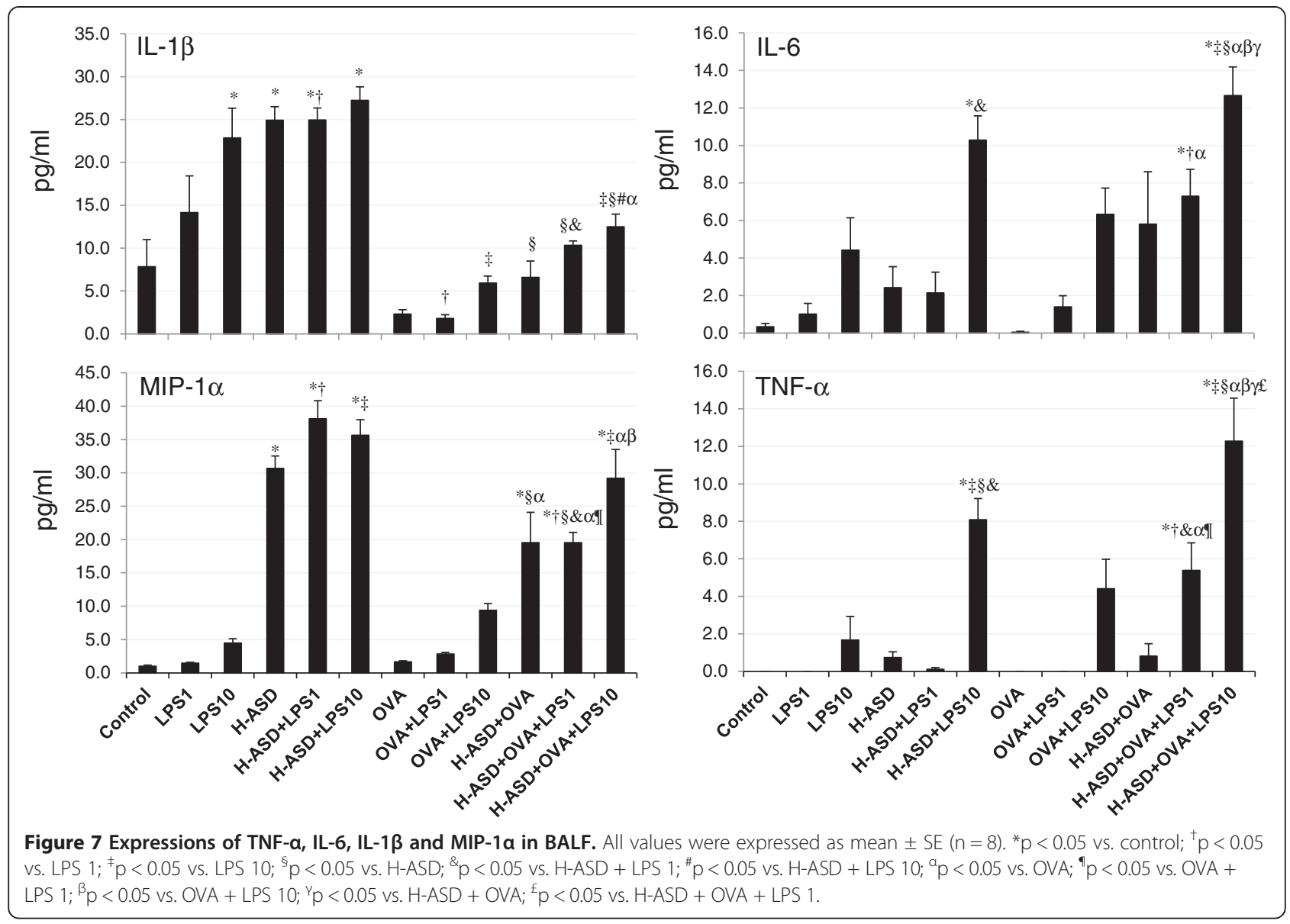

$\mathrm{H}-\mathrm{ASD}+\mathrm{OVA}$ and H-ASD + OVA + LPS 10 increased to similar levels of OVA-specific IgE. H-ASD + OVA + LPS 1 increased the level of the IgE and IgG1 in serum most effectively.

\section{Discussion}

Exposure to LPS is known to be a significant risk factor for increased asthma prevalence and severity [21,22]. Therefore, LPS contaminated ASD may cause aggravation of allergic lung inflammation. Previous reports have demonstrated that co-treatment of TLR2-ligand Pam3Cys and OVA activated an OVA-associated Th2-biased immune response in experimental asthma [23]. Therefore, ultrapure LPS was used in this study because the LPS made commercially is contaminated with TLR2-ligands. Before beginning the in vivo experiment, we investigated whether our ultra-pure LPS would act only on TLR4 or not using BMDMs of WT, TLR2 KO, TLR $4 \mathrm{KO}$ and MyD88 KO mice. As shown in Figure 1, this LPS exhibited no response to the production of cytokines (TNF- $\alpha$ and IL-6) in BMDMs from TLR4 KO, but from TLR2 KO.

Previous studies have reported that LPS inhaled in low levels $(0.1 \mu \mathrm{g})$ enhanced Th2 responses to inhaled OVA in a mouse model of Th2 pulmonary inflammation, while inhalation of high levels $(10 \mu \mathrm{g}, 100 \mu \mathrm{g})$ of LPS with an antigen caused a Th1 response [16,17].

In the absence of OVA, 10 ng LPS alone caused a slight increase of neutrophils in BALF, but $1 \mathrm{ng}$ LPS was less effective than $10 \mathrm{ng}$ LPS. However in the presence of H-ASD, 10 ng LPS caused a marked increase of neutrophils in BALF along with the proinflammatory mediators IL-12, RANTES, MCP-1, IL-6, and TNF- $\alpha$. Pathologically, 10 ng LPS caused moderate bronchitis and alveolitis, suggesting that H-ASD aggravates LPS-induced lung inflammation via the increased proinflammatory mediators.

In the presence of OVA, LPS at the levels of $1 \mathrm{ng}$ and $10 \mathrm{ng}$ caused a slight increase of eosinophils (Figure 2). LPS at the level of $10 \mathrm{ng}$ caused a moderate increase of neutrophils along with proinflammatory mediators IL-12, KC, RANTES, MCP-1, IL- 6 and TNF- $\alpha$ in BALF, but the induction of Th2 cytokines IL-5, IL-13 occurred only at trace levels, suggesting that OVA + LPS 10 does not serve to induce strong Th2 responses.

In the presence of H-ASD + OVA, LPS at the levels of $1 \mathrm{ng}$ and $10 \mathrm{ng}$ increased neutrophil and eosinophi numbers. In particular, 10 ng LPS increased more proinflammatory cytokines (IL-1 $\beta$, IL-6, IL-12, IL-17A, TNF- $\alpha$ ) and chemokines (RANTES, MIP-1 $\alpha$, KC, MCP-1, Eotaxin, 

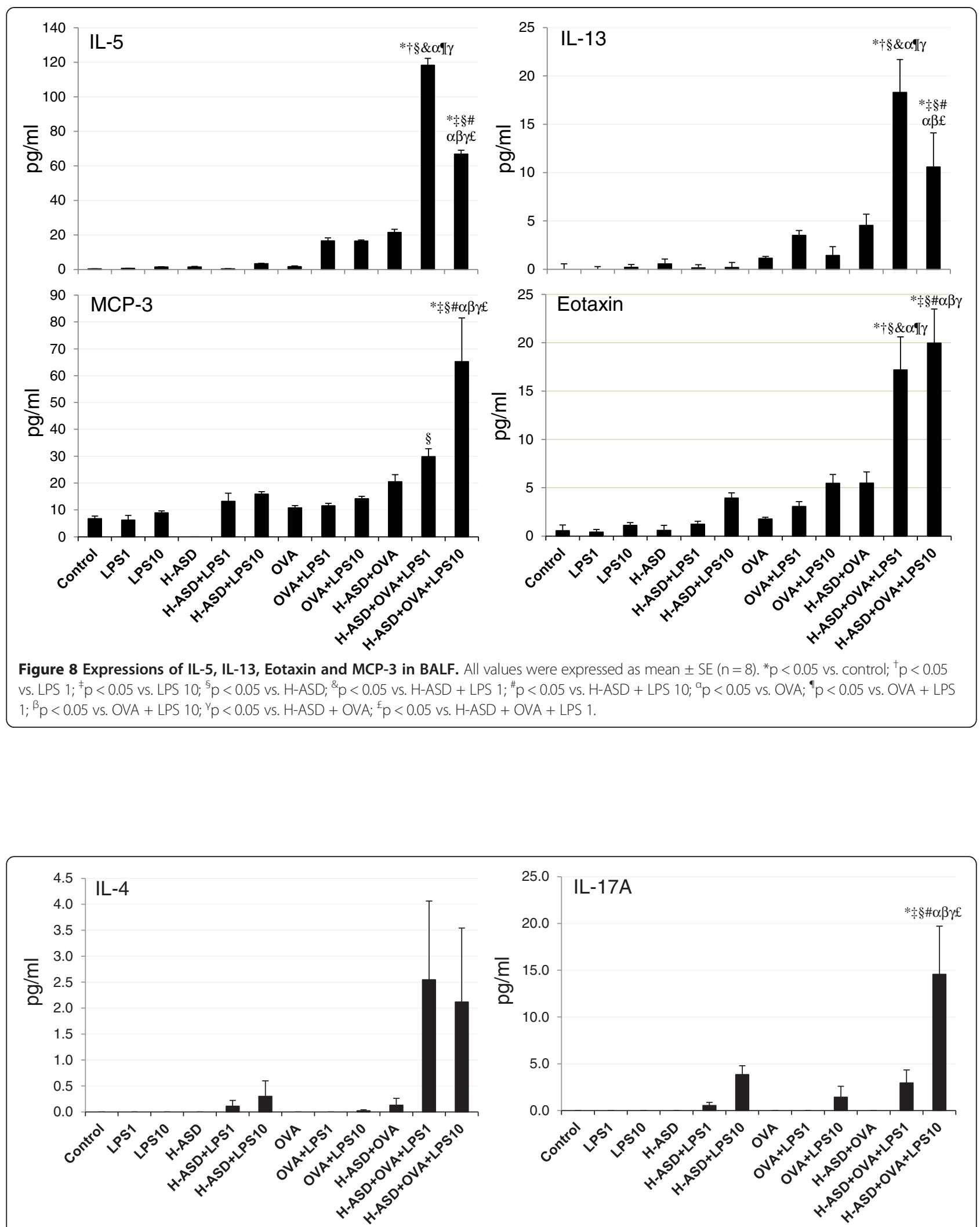

Figure 9 Expressions of IL-4 and IL-17A in BALF. All values were expressed as mean $\pm S E(n=8) .{ }^{*} p<0.05$ vs. control; ${ }^{\dagger} p<0.05$ vs. LPS $1 ;{ }^{\ddagger} p<0.05$ vs. LPS 10; ${ }^{\S} p<0.05$ vs. H-ASD; ${ }^{\circledR} p<0.05$ vs. H-ASD + LPS $1 ;{ }^{*} p<0.05$ vs. H-ASD + LPS $10 ;{ }^{a} p<0.05$ vs. OVA; ${ }^{\beta} p<0.05$ vs. OVA + LPS $1 ;{ }^{\gamma} p<0.05$ vs. H-ASD + OVA; ${ }^{⿷} \mathrm{p}<0.05$ vs. H-ASD + OVA + LPS 1. 

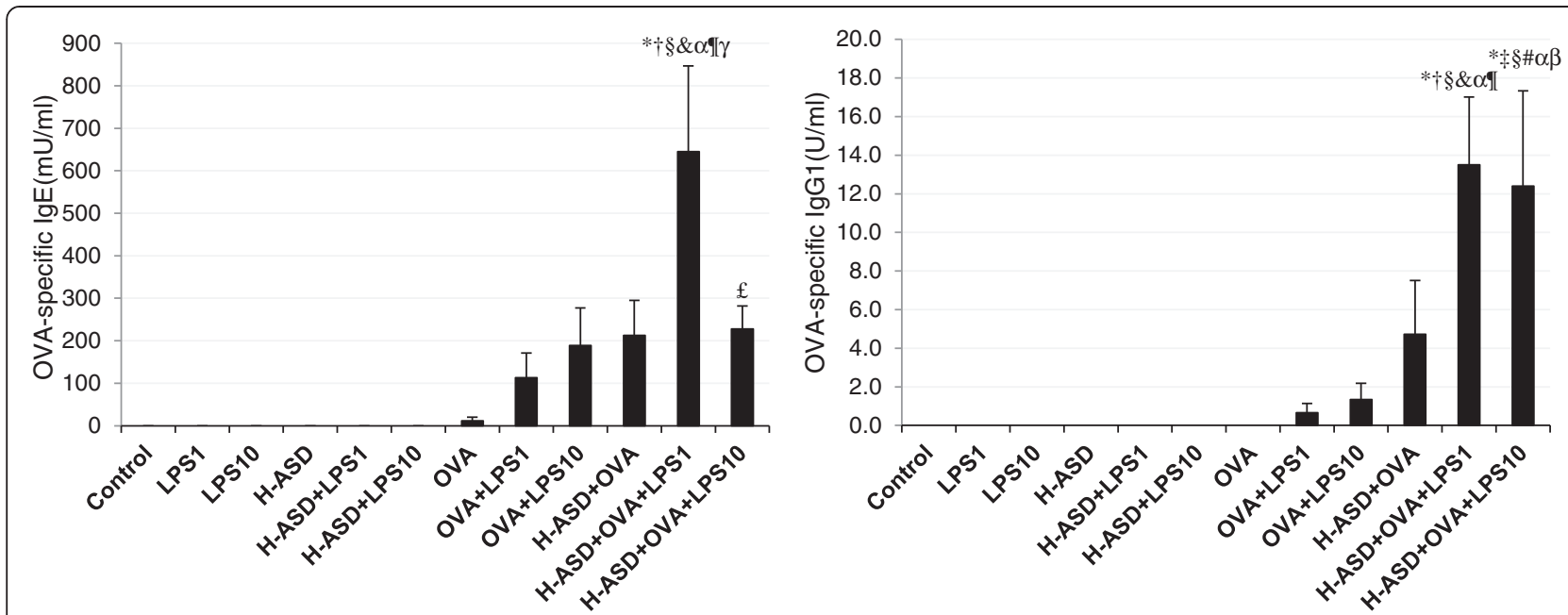

Figure 10 Effects of test samples on IgE and IgG1 production in serum. According to the manufacturer's protocol, $1 \mathrm{U}$ of the anti-OVA IgE is defined as $1.3 \mathrm{ng}$ of the antibody and $1 \mathrm{U}$ of the anti-OVA IgG1 is defined as $160 \mathrm{ng}$ of the antibody. All values were expressed as mean $\pm \mathrm{SE}$. ${ }^{*} p<0.05$ vs. control; ${ }^{\dagger} p<0.05$ vs. LPS $1 ;{ }^{\ddagger} p<0.05$ vs. LPS $10 ;{ }^{\S} p<0.05$ vs. H-ASD; ${ }^{\circledR} p<0.05$ vs. H-ASD + LPS $1 ;{ }^{\#} p<0.05$ vs. H-ASD + LPS $10 ;$ ${ }^{a} p<0.05$ vs. OVA; ${ }^{q} p<0.05$ vs. OVA + LPS $1 ;{ }^{\beta} p<0.05$ vs. OVA + LPS $10 ;{ }^{\gamma} p<0.05$ vs. H-ASD + OVA; ${ }^{\ddagger} p<0.05$ vs. H-ASD + OVA + LPS 1.

MCP-3) in BALF than 1 ng LPS (Figures 6, 7, 8). However, The pathological changes-eosinophil recruitment in the submucosa of the airway along with proliferation of goblet cells in the bronchial epithelium in the airway- and Th2 cytokines IL-5/IL-13 induced by 1 ng LPS were more remarkable than 10 ng LPS, suggesting that co-exposure to H-ASD and LPS, particularly $1 \mathrm{ng}$ LPS, can lead to Th2 responses to inhaled OVA more than $10 \mathrm{ng}$ LPS can. The Th2 cytokines together with increased eosinophil-relevant chemokines eotaxin and MCP-3 aggravated eosinophilic lung inflammation in the present study.

Overall, H-ASD played an important role in the exacerbation of pathological changes (Figure 3). Eosinophils are reportedly implicated in tissue destruction in allergic asthma [24]. Because toxic eosinophil-derived proteins, such as major basic proteins, cause bronchial mucosal damage in asthmatic airways, they may exacerbate the symptoms of asthma [25]. IL-5 generated from Th2 cells attracts and activates eosinophils, which are implicated in tissue destruction in allergic asthma [26]. IL-13 has been shown to stimulate B cells and subsequently produce antigen specific antibodies [27]. It also promotes mucous secretion and the production of mucous cells, such as goblet cells, in the bronchial epithelium [28]. Therefore, airway injury resulting from co-treatment may be due to exacerbation of eosinophilic airway-inflammation. This allergic airway inflammation recruits not only eosinophils, but also neutrophils. There is a report that IL-17A contributes to neutrophil infiltration in airway inflammation in allergic asthma [29].

Toll like receptors (TLRs) are pattern recognition receptors (PRRs) that play an essential role in animal immunity [30]. TLR4 is well known as a receptor for LPS. Previous in vivo findings indicate that low levels of LPS can cause TLR4-dependent Th2 responses to OVA [16,31]. Low levels of LPS activate Th2 responses to OVA through the adaptor protein myeloid differentiation factor 88 (MyD88) [32]. In this animal study, the induction of pro-inflammatory molecules in BALF may be a TLR4dependent signaling pathway, but not a TLR2 pathway, because there is no contamination of TLR2-ligands in LPS from as a result of the in vitro experiment. In the presence of OVA, Th2 responses to $1 \mathrm{ng}$ and $10 \mathrm{ng}$ LPS were defective. Interestingly, in the presence of OVA and H-ASD, the two doses of LPS, especially the $1 \mathrm{ng}$ dose markedly enhanced Th2 responses. This may have been caused by a TLR4-dependent signaling pathway through MyD88. In both the presence and absence of OVA, low dose LPS caused no response in the form of induction of Th1 cytokine IFN- $\gamma$, suggesting that low doses of LPS lack the potency for leading to a Th1 response. Interferon $\gamma$ reportedly inhibits the development of secondary allergic responses in mice [33]. Therefore, we speculate that the lack of IFN- $\gamma$ skews lung inflammation in a Th2 direction. However, the present study did not provide sufficient evidence to explain the role of H-ASD in enhancement of Th2 responses. Our previous in vitro study has shown that H-ASD treatment in the presence of LPS dose-dependently enhanced the production of inflammatory mediators by BMDMs from ICR mice [18]. In this in vivo study, co-exposure to H-ASD and LPS enhanced neutrophilic inflammation and the production of inflammatory mediators in BALF. An increase in antigen presenting cells, such as macrophages, caused by H-ASD (Figure 2) and the activation of the TLR4-signaling pathway leading to inflammatory cytokine production 
by $\mathrm{H}$-ASD may lead to an adaptive immune response related to Th2. Although the pathway leading to Th2 activation is unclear in this study, it is clear that H-ASD has potential to elicit a weak reaction by adding a low dose of LPS. Similar potential of H-ASD has been observed in lung inflammation caused by Gram negative bacteria, Klebsiella Pneumoniae [34] and fungi, Bjerkandera adusta [35].

On the other hand, in the presence of H-ASD and OVA, low doses of LPS caused the production of OVA-specific IgE and IgG1 in serum. It seems that these increases are being interlocked with activation of Th2 response caused by these mixtures. $\mathrm{H}$-ASD used contains $14.3 \% \mathrm{Al}_{2} \mathrm{O}_{3}$. $\mathrm{Al}$ though aluminum adjuvant is well known, $\mathrm{Al}_{2} \mathrm{O}_{3}$ may not contribute to the adjuvant effect. The adjuvant effect of $\mathrm{Al}_{2} \mathrm{O}_{3}$ particle on their immunoglobulin productions was not detected in our previous study [36]. However, $\mathrm{SiO}_{2}$ is a possible adjuvant. Allergen-specific antibodies may contribute to the occurrence of inflammatory cell accumulation after an allergen challenge via IgE-mediated degranulation of mast cells [37]. Antigen-specific IgG1 can cause degranulation via an Fcg RII receptor on the eosinophil's surface [38]. Therefore, antibodies may play an important role in the aggravation of lung eosinophilia caused by H-ASD + OVA + LPS.

\section{Conclusions}

This study demonstrates that LPS contamination in ASD aggravates allergic lung inflammation in the presence of OVA and H-ASD. The aggravation of the allergic lung inflammation by LPS may be caused through the TLR4dependent signaling pathway. The results of the current study indicate that the exposure to ASD with LPS may be a significant risk factor for adult and child asthma. The hazardous effects of mineral dust and biogenic agents on human respiratory disease are an increasing public concern. Atmospheric exposure to bacteria, fungi and virus, and silica-carrying particulate matters may influence human respiratory health on a world-wide scale.

\section{Abbreviations}

ASD: Asian sand dust; LPS: Lipopolysaccharide; BALF: Bronchoalveolar lavage fluid; BMDM: Bone marrow-derived macrophages; ELISA: Enzyme-linked immunosorbent assays; EMSA: Electrophoretic mobility shift assay; H-ASD: Heated Asian sand dust; IFN-ү: Interferon- $\gamma ;$ IL: Interleukin; KC: Keratinocyte chemoattractant; MCP-1: Monocyte chemotactic protein-1; MCP-3: Monocyte chemotactic protein-3; MIP-1a: Macrophage inflammatory protein-1a; RANTES: Regulated on activation normal T cell expressed and presumably secreted; TNF-a: Tumor necrosis factor-a; TGF- $\beta$ : Transforming growth factor- $\beta$; TLR: Toll like receptor.

\section{Competing interest}

The authors declare that they have no competing interest.

\section{Authors' contributions}

TI designed the research. YR, MH, YS, YY, SY, HT, and MN conducted the experiments. YR, TI and TS analyzed the data and wrote the manuscript. TI and GS had primary responsibility for final content. All authors read and approved the final manuscript.

\section{Acknowledgments}

This study was supported in part by grants from the Ministry of Education, Culture, Sports, Science and Technology of Japan (No.22241011) and the Global Environment Research Fund of the Ministry of the Environment Japan (5C-1155). We appreciate the vital contribution of students at Oita University of Nursing and Health Sciences in this research.

\section{Author details}

'Department of Nutritional and Food Hygiene, College of Public Health, China Medical University, Shenyang, China. ${ }^{2}$ Department of Health Sciences, Oita University of Nursing and Health Sciences, Oita 870-1201, Japan. ${ }^{3}$ Department of Environmental and Occupational Health, College of Public Health, China Medical University, Shenyang, China. ${ }^{4}$ Department of Immunology and Parasitology, School of Medicine, University of Occupational and Environmental Health, Japan, Fukuoka 807-8555, Japan. ${ }^{5}$ Environmental Chemistry Division, National Institute for Environmental Studies, Ibaraki 305-8506, Japan. ${ }^{6}$ Environmental Health Division, Department of Environmental Engineering, Graduate School of Engineering, Kyoto University, Kyoto 615-8530, Japan. ${ }^{7}$ Department of Environmental Toxicology, University of California, Davis, CA 95616, USA.

Received: 13 March 2014 Accepted: 3 May 2014

Published: 9 June 2014

\section{References}

1. Duce RA, Unni CK, Ray BJ, Prospero JM, Merrill JT: Long-range atmospheric transport of soil dust from Asia to the tropical north pacific: temporal variability. Science 1980, 209(4464):1522-1524.

2. Husar RB, Tratt DB, Schichtel BA, Falke SR, Li F, Jaffe D, Gasso' S, Gill T, Laulainen NS, Lu F, Reheis MC, Chun Y, Westphal D, Holben BN, Gueymard C, McKendry I, Kuring N, Feldman GC, McClain C, Frouin RJ, Merrill J, DuBois D, Vignola F, Murayama T, Nickovic S, Wilson WE, Sassen K, Sugimoto N, Malm WC: Asian dust events of april 1998. J Geophys Res 2001, 106:18316-18330.

3. Kim BG, Han JS, Park SU: Transport $\mathrm{SO}_{2}$ and aerosol over the Yellow Sea. Atmos Environ 2001, 35:727-737.

4. Kwon HJ, Cho SH, Chun Y, Lagarde F, Pershagen G: Effects of the Asian dust events on daily mortality in Seoul, Korea. Environ Res 2002, 90(1):1-5.

5. Chen YS, Sheen PC, Chen ER, Liu YK, Wu TN, Yang CY: Effects of Asian dust storm events on daily mortality in Taipei, Taiwan. Environ Res 2004, 95(2):151-155.

6. Watanabe M, Yamasaki A, Burioka N, Kurai J, Yoneda K, Yoshida A, Igishi T, Fukuoka Y, Nakamoto M, Takeuchi H, Suyama H, Tatsukawa T, Chikumi H, Matsumoto S, Sako T, Hasegawa Y, Okazaki R, Horasaki K, Shimizu E: Correlation between Asian dust storms and worsening asthma in Western Japan. Allergol Int 2011, 60:267-275.

7. Kanatani KT, Ito I, Al-Delaimy WK, Adachi Y, Mathews WC, Ramsdell JW, Toyama Asian Desert Dust and Asthma Study Team: Desert dust exposure is associated with increased risk of asthma hospitalization in children. Am J Respir Crit Care Med 2010, 182(12):1475-1481.

8. Ichinose T, Yoshida S, Hiyoshi K, Sadakane K, Takano H, Nishikawa M, Mori I, Yanagisawa R, Kawazato H, Yasuda A, Shibamoto T: The effects of microbial materials adhered to Asian sand dust on allergic lung inflammation. Arch Environ Contam Toxicol 2008, 55(3):348-357.

9. He M, Ichinose T, Yoshida S, Nishikawa M, Mori I, Yanagisawa R, Takano H, Inoue $\mathrm{K}$, Sun G, Shibamoto T: Airborne Asian sand dust enhances murine lung eosinophilia. Inhal Toxicol 2010, 22(12):1012-1025.

10. Kim W, Doh SJ, Yu Y, Lee M: Role of Chinese wind-blown dust in enhancing environmental pollution in Metropolitan Seoul. Environ Pollut 2008, 153:333-341.

11. Chen PS, Tsai FT, Lin CK, Yang CY, Chan CC, Young CY, Lee CH: Ambient influenza and avian influenza virus during dust storm days and background days. Environ Health Perspect 2010, 118(9):1211-1216.

12. Maki T, Susuki S, Kobayashi F, Kakikawa M, Tobo Y, Yamada M, Higashi T, Matsuki A, Hong C, Hasegawa $H$, Iwasaka Y: Phylogenetic analysis of atmospheric halotolerant bacterial communities at high altitude in an Asian dust (KOSA) arrival region. Suzu City Sci Total Environ 2010, 408(20):4556-4562. 
13. Braun-Fahrländer $C$, Riedler J, Herz U, Eder W, Waser M, Grize L, Maisch S, Carr D, Gerlach F, Bufe A, Lauener RP, Schierl R, Renz H, Nowak D, von Mutius E: Allergy and Endotoxin Study Team. Environmental exposure to endotoxin and its relation to asthma in school-age children. $N$ Engl J Med 2002, 347(12):869-877.

14. Thorne PS, Kulhánková K, Yin M, Cohn R, Arbes SJ Jr, Zeldin DC: Endotoxin exposure is a risk factor for asthma: the national survey of endotoxin in United States housing. Am J Respir Crit Care Med 2005, 172(11):1371-1377.

15. Wickens K, Lane JM, Fitzharris P, Siebers R, Riley G, Douwes J, Smith T, Crane $\mathrm{J}$ : Farm residence and exposures and the risk of allergic diseases in New Zealand children. Allergy 2002, 57(12):1171-1179.

16. Eisenbarth SC, Piggott DA, Huleatt JW, Visintin I, Herrick CA, Bottomly K: Lipopolysaccharide-enhanced, toll-like receptor 4-dependent T helpe cell type 2 responses to inhaled antigen. J Exp Med 2002, 196(12):1645-1651.

17. Kim YK, Oh SY, Jeon SG, Park HW, Lee SY, Chun EY, Bang B, Lee HS, Oh MH, Kim YS, Kim JH, Gho YS, Cho SH, Min KU, Kim YY, Zhu Z: Airway exposure levels of lipopolysaccharide determine type 1 versus type 2 experimental asthma. J Immunol 2007, 178(8):5375-5382.

18. He M, Ichinose T, Song Y, Yoshida Y, Arashidani K, Yoshida S, Liu B, Nishikawa M, Takano H, Sun G: Effects of two Asian sand dusts transported from the dust source regions of Inner Mongolia and northeast China on murine lung eosinophilia. Toxicol Appl Pharmacol 2013, 272(3):647-655.

19. Masataka Nishikawa M, Dashdondog Batdor D, Ukachi M, Onishi K, Nagan K, Mori I, Matsui I, Sano T: Preparation and chemical characterisation of an Asian mineral dust certified reference material. Anal Methods 2013, 5:4088-4095.

20. He M, Ichinose T, Yoshida S, Takano H, Nishikawa M, Sun G, Shibamoto T: Induction of immune tolerance and reduction of aggravated lung eosinophilia by co-exposure to Asian sand dust and ovalbumin for 14 weeks in mice. Allerg Asthma Clin Immunol 2013, 9:19-29.

21. Alexis NE, Eldridge MW, Peden DB: Effect of inhaled endotoxin on airway and circulating inflammatory cell phagocytosis and CD11b expression in atopic asthmatic subjects. J Allergy Clin Immunol 2003, 112(2):353-361.

22. Smit LA, Heederik D, Doekes G, Blom C, van Zweden I, Wouters IM: Exposure-response analysis of allergy and respiratory symptoms in endotoxin-exposed adults. Eur Respir J 2008, 31(6):1241-1248.

23. Redecke V, Häcker H, Datta SK, Fermin A, Pitha PM, Broide DH, Raz E: Cutting edge: activation of toll-like receptor 2 induces a Th2 immune response and promotes experimental asthma. J Immunol 2004, 172:2739-2743.

24. Kidd P: Th1/Th2 balance: the hypothesis, its limitations, and implications for health and disease. Altern Med Rev 2003, 8:223-246.

25. Bradley BL, Azzawi M, Jacobson M, Assoufi B, Collins JV, Irani AM, Schwartz LB, Durham SR, Jeffery PK, Kay AB: Eosinophils, T-lymphocytes, mast cells, neutrophils, and macrophages in bronchial biopsy specimens from atopic subjects with asthma: comparison with biopsy specimens from atopic subjects without asthma and normal control subjects and relationship to bronchial hyperresponsiveness. J Allergy Clin Immunol 1991, 88(4):661-674.

26. Foster PS, Hogan SP, Ramsay AJ, Matthaei KI, Young IG: Interleukin 5 deficiency abolishes eosinophilia, airways hyperreactivity, and lung damage in a mouse asthma model. J Exp Med 1996, 183(1):195-201.

27. Mosmann TR, Coffman RL: TH1 and TH2 cells: different patterns of lymphokine secretion lead to different functional properties. Annu Rev Immunol 1989, 7:145-173.

28. Tesfaigzi $Y$ : Regulation of mucous cell metaplasia in bronchial asthma. Curr Mol Med 2008, 8:408-415.

29. Iwakura Y, Nakae S, Saijo S, Ishigame H: The roles of IL-17A in inflammatory immune responses and host defense against pathogens. Immunol Rev 2008, 226:57-79.

30. Medzhitov R: Toll-like receptors and innate immunity. Nat Rev Immunol 2001, 1(2):135-145.

31. Dabbagh K, Dahl ME, Stepick-Biek P, Lewis DB: Toll-like receptor 4 is required for optimal development of Th2 immune responses: role of dendritic cells. J Immunol 2002, 168:4524-4530.

32. Piggott DA, Eisenbarth SC, Xu L, Constant SL, Huleatt JW, Herrick CA Bottomly K: MyD88-dependent induction of allergic Th2 responses to intranasal antigen. J Clin Invest 2005, 115(2):459-467.
33. Lack G, Bradley KL, Hamelmann E, Renz H, Loader J, Leung DY, Larsen G, Gelfand EW, Nebulized: IFN-gamma inhibits the development of secondary allergic responses in mice. J Immunol 1996, 157(4):1432-1439.

34. He M, Ichinose T, Yoshida S, Yamamoto S, Inoue K, Takano H, Yanagisawa R, Nishikawa M, Mori I, Sun G, Shibamoto T: Asian sand dust enhances murine lung inflammation caused by Klebsiella pneumonia. Toxicol Appl Pharmacol 2012, 258(2):237-247.

35. Liu B, Ichinose T, He M, Naoyuki Kobayashi F, Maki T, Yoshida S, Yoshida Y, Arashidani K, Takano H, Nishikawa M, Sun G, Shibamoto T: Lung inflammation by fungus, Bjerkandera adusta isolated from Asian sand dust (ASD) aerosol and enhancement of ovalbumin -induced lung eosinophilia by ASD and the fungus in mice. Allerg Asthma Clin Immunol 2014, 10:10.

36. Ichinose T, Yoshida S, Sadakane K, Takano H, Yanagisawa R, Inoue K, Nishikawa M, Mori I, Kawazato H, Yasuda A, Shibamoto T: Effects of asian sand dust, Arizona sand dust, amorphous silica and aluminum oxide on allergic inflammation in the murine lung. Inhal Toxicol 2008, 20:685-694.

37. Zweiman B: The late-phase reaction: role of $\lg \mathrm{E}$, its receptor and cytokines. Curr Opin Immunol 1993, 5:950-955.

38. Kaneko M, Swanson MC, Gleich GJ, Kita H: Allergen-specific lgG1 and lgG3 through Fc gamma RII induce eosinophil degranulation. J Clin Invest 1995, 95(6):2813-2821.

doi:10.1186/1710-1492-10-30

Cite this article as: Ren et al:: Enhancement of OVA-induced murine lung eosinophilia by co-exposure to contamination levels of LPS in Asian sand dust and heated dust. Allergy, Asthma \& Clinical Immunology 2014 10:30

\section{Submit your next manuscript to BioMed Central and take full advantage of:}

- Convenient online submission

- Thorough peer review

- No space constraints or color figure charges

- Immediate publication on acceptance

- Inclusion in PubMed, CAS, Scopus and Google Scholar

- Research which is freely available for redistribution 